\title{
Angiotensin Converting Enzyme (ACE) Inhibition Activity by Syzygium polyanthum Wight (Walp.) Leaves: Mechanism and Specificity
}

\author{
A Ismail ${ }^{1, *}$, TAFT Anuar ${ }^{2}$, IFM Suffian ${ }^{3}$, AA Abdul Hamid ${ }^{4}$, MN Omar ${ }^{4}$, BE Mustafa $^{1}$, WAN Wan Ahmad ${ }^{5}$
}

\section{A Ismail ${ }^{1, *}$, TAFT Anuar', IFM \\ Suffian ${ }^{3}$, AA Abdul Hamid ${ }^{4}$, MN \\ Omar' $^{4}$, BE Mustafa ${ }^{1}$, WAN Wan \\ Ahmad $^{5}$}

'Department of Fundamental Dental and Medical Sciences, Kulliyah of Dentistry, International Islamic University Malaysia, 25200 Kuantan, Pahang, MALAYSIA.

2Department of Chemistry, Kulliyyah of Science, International Islamic University Malaysia, 25200 Kuantan, Pahang,

MALAYSIA.

${ }^{3}$ Department of Pharmaceutical Chemistry, Kulliyyah of Pharmacy, International Islamic University Malaysia, 25200 Kuantan, Pahang MALAYSIA.

${ }^{4}$ Department of Biotechnology, Kulliyyah of Science, International Islamic University Malaysia, 25200 Kuantan, Pahang,

MALAYSIA.

${ }^{5}$ Biomedicine Programme, School of Health Sciences, Universiti Sains Malaysia, Health Campus, 16150 Kubang Kerian, Kelantan, MALAYSIA.

\section{Correspondence}

\section{A Ismail}

Department of Fundamental Dental and Medical Sciences, Kulliyah of Dentistry, International Islamic University Malaysia, 25200 Kuantan, Pahang, MALAYSIA.

E-mail: dr_azlini@iium.edu.my

History

- Submission Date: 18-11-2021;

- Review completed: 23-12-2021;

- Accepted Date: 03-01-2022.

DOI : 10.5530/pj.2022.14.11

Article Available online

http://www.phcogj.com/v14/i1

\section{Copyright}

(C) 2022 Phcogj.Com. This is an openaccess article distributed under the terms of the Creative Commons Attribution 4.0 International license.

\begin{abstract}
Introduction: One of the potential antihypertensive mechanisms include angiotensin converting enzyme (ACE) inhibition. So far, there is no in-depth study on the ACE inhibition activity of S. polyanthum, an ethnomedicinal plant used in treating hypertension. Thus, we aimed to study the ACE inhibition activity of S. polyanthum leaves by evaluating its potency, mechanism, and specificity. Methods: S. polyanthum leaves were macerated in a bath-sonicator with either water, methanol, ethyl acetate, and hexane producing aqueous (ASP), methanolic (MSP), ethyl acetate (EASP) and hexane (HSP) extracts. Each extract $(100 \mu \mathrm{g} / \mathrm{mL})$ were initially screened for ACE inhibition activity and then compared with standard drug, captopril $(2.06 \mathrm{ng} / \mathrm{mL})$, then the most active extract was further tested at 1 to $1000 \mu \mathrm{g} / \mathrm{ml}$. Inhibition mechanism was studied using zinc chloride and bovine serum albumin (BSA), while inhibition specificity was determined upon screening for a-chymotrypsin and trypsin inhibition activity. Results: ASP at $100 \mu \mathrm{gg} /$ $\mathrm{mL}$ exhibited the highest inhibition activity $(69.43 \pm 0.60 \%)$ compared to MSP $(41.63 \pm 0.15 \%)$, EASP $(9.62 \pm 1.60 \%)$, and HSP $(45.40 \pm 0.15 \%)$. ASP showed dose-dependent ACE inhibition activity with IC of $41 \mu \mathrm{g} / \mathrm{mL}$. ASP's ACE inhibition activity was significantly reduced in the presence of BSA, but not upon the presence of zinc chloride. ASP did not significantly inhibit a-chymotrypsin and trypsin. Conclusion: This study showed that the enzyme inhibition activity by S. polyanthum leaves was specific towards ACE. The ACE inhibition possibly occurs via protein precipitation and was non-dependent to the chelation with zinc at ACE active site.

Key words: Antihypertensive, ACE, Angiotensin converting enzyme, Hypertension, Syzygium polyanthum
\end{abstract}

\section{INTRODUCTION}

Hypertension is an alarming disease condition characterized by a persistent rise in blood pressure. Hypertension has become more common, especially in low- and middle-income countries (31.5\%, 1.04 billion people). ${ }^{1}$ Hypertension is a major risk factor for coronary heart disease and stroke, in which uncontrolled blood pressure may lead to various detrimental consequences such as hemorrhagic and ischemic stroke, myocardial infarction, acute coronary syndrome, heart failure, and even death. ${ }^{2}$

There are a variety of antihypertensive medications on the market that target distinct processes or pathways. Angiotensin-converting enzyme inhibitors, such as captopril and lisinopril, are a class of medications that reduce peripheral vascular resistance by blocking the synthesis of angiotensin II, a potent vasoconstrictor. ACE inhibitors are commonly used to treat hypertension, however they have been linked to side effects such as angioedema, foetal toxicity, and persistent dry cough in some people. ${ }^{3}$ As a result, research is still ongoing to find medications that are similarly effective with less side effects.

Plant is one of the rich natural resources for drug discovery. Syzygium polyanthum, also known as "serai kayu" or "salam" in Malaysia, is a Malay ethnomedicinal plant that has traditionally been used to alleviate hypertension. S. polyanthum leaves are used in cooking to impart a distinct flavor and they are also eaten raw as "ulam" especially among people in Kelantan, a state in the East coast Malaysia. S. polyanthum also has various bioactivities including antioxidant, antidiabetic, antimicrobial, anti-cancer, anti-tumour, dental plaque inhibition, lipid lowering, acetylcholine-esterase inhibition, antidiarrheal, and also anti-hypertensive properties. ${ }^{4}$

Previous researches have reported the efficacy of S. polyanthum leaves as anti-hypertensive agent in normal and hypertensive rats model. ${ }^{5-7} \mathrm{~A}$ preliminary ACE inhibition study has shown that $100 \mathrm{ppm}$ of ethanolic extract of $S$. polyanthum leaves has ACE inhibitory activity of $53.97 \pm 0.95 \%{ }^{8}$ and thus was considered as an active extract. ${ }^{9}$ Despite the fact that $S$. polyanthum leaves extract is an active extract for ACE inhibition, no additional research has been done to assess its potency (inhibition concentration at $50 \%$ or $\mathrm{IC}_{50}$ ) or to investigate its mechanism and specificity of inhibition. This work intends to investigate the ACE inhibition activity of $S$. polyanthum leaves, as well as its inhibition mechanism and specificity, in order to close this gap.

\section{MATERIALS AND METHODS}

\section{Plant collection and authentication}

Approximately, $3.26 \mathrm{~kg}$ of the plant leaves were collected from Taman Pertanian Jubli Perak, Kuantan, Pahang, Malaysia in May 2019. The plant used in this study was verified as Syzygium polyanthum (Wight) Walp by a botanist on 24th July 2019. The voucher herbarium specimen (PIIUM 
0282-1) was kept in Herbarium at Kulliyyah of Pharmacy, International Islamic University Malaysia (IIUM), Kuantan, Pahang.

\section{Extraction}

The leaves were dried for three weeks at room temperature in the open air at the Natural Product Laboratory of the Kulliyyah of Science, IIUM. Before extraction, the dried leaves were crushed into powder in a laboratory blender. The ultrasonic aided extraction (UAE) technique was used to extract the powdered sample. ${ }^{7}$ Powdered sample (250 g) was soaked in a pre-heated distilled water at $80{ }^{\circ} \mathrm{C}$ using a hot plate for three cycles of $1200 \mathrm{~mL}$ (first cycle), 600 (second cycle) $\mathrm{mL}$, and 600 (third cycle) $\mathrm{mL}$ of distilled water. In between each cycle, the soaked sample was sonicated using a bath-sonicator at the frequency ranging from 40 to $80 \lambda$ for 30 minutes. All sonicated samples from the three cycles were then filtrated with Whatmann filter paper No. 1 , combined, and then stored in $-80^{\circ} \mathrm{C}$ freezer and freeze-dried for 12 days. This lyophilized sample was designated as the aqueous extract of $S$. polyanthum (ASP). All samples were stored at $-4{ }^{\circ} \mathrm{C}$ chiller prior to the subsequent study.

For solvent sequential extraction, $250 \mathrm{~g}$ of powdered S. polyanthum leaves was macerated in $700 \mathrm{~mL}$-hexane. The macerated sample was then sonicated using a bath-sonicator at room temperature at a frequency range from 40-80 $\lambda$. After 30 minutes, the mixture was filtered with Whatmann filter paper No. 1. The filtrate was further concentrated via a rotary evaporator and this concentrated form was then designated as the hexane extract of S. polyanthum (HSP) and stored at $-4{ }^{\circ} \mathrm{C}$ chiller.

The remaining residue from hexane extraction was then macerated again in $700 \mathrm{~mL}$ of ethyl acetate solvent. The mixture was then put in a bath sonicator with similar settings, $24^{\circ} \mathrm{C}$ and $40-80 \lambda$ for 30 minutes. Post-sonication, the mixture was filtered via Whatmann filter paper No. 1, which then further concentrated using a rotary evaporator. The filtrate was named the ethyl acetate extract of $S$. polyanthum (EASP) and stored at $-4{ }^{\circ} \mathrm{C}$ chiller.

The final solvent to be extracted was the methanol solvent. Like EASP, the residue remnants were soaked again in methanol solvent before sonication in a bath-sonicator with a similar setting of $24^{\circ} \mathrm{C}, 40-80 \lambda$ for 30 minutes. Then, the mixture was filtered using Whatmann filter paper No. 1. The filtrate was then evaporated further using a rotary evaporator and was designated as methanol extract of $S$. polyanthum (MSP). MSP was then stored in a $-4{ }^{\circ} \mathrm{C}$ chiller. The percentage yield of all extracts was calculated using Equation 1 as shown below:

Percentage Yield $\%=\frac{\text { Mass of crude extract }}{\text { Mass of dry sample }} \times 100$

\section{Angiotensin-Converting Enzyme (ACE) inhibitory activity}

ACE inhibition assay using spectrophotometric method based on Cushman \& Cheung (1971) was employed in this study..$^{10}$ The stock solution for each extract was prepared by dissolving $1 \mathrm{mg}$ of each extract with one $\mathrm{ml}$ of its respective solvent. All solution extracts were then further diluted in $0.1 \mathrm{M}$ potassium phosphate buffer solution containing $0.2 \mathrm{M}$ sodium chloride $(\mathrm{NaCl})$ to a concentration of 100 $\mu \mathrm{g} / \mathrm{mL}$. The standard drug, captopril, was prepared by dissolving in distilled water before further diluting it to achieve the concentration of $2.06 \mathrm{ng} / \mathrm{mL}$ based on its $\mathrm{IC}_{50}$ value for ACE inhibition as reported in a previous study. ${ }^{11}$

Fifty $\mu \mathrm{L}$ of the sample was then added with $50 \mu \mathrm{L}$ of $0.05 \mathrm{mU} / \mu \mathrm{L}$ ACE enzyme before pre-incubation at $37{ }^{\circ} \mathrm{C}$ for 10 minutes. After the mixture was treated with $150 \mu \mathrm{L}$ of $6.5 \mathrm{mM}$ hippuryl-histidiylleucine (HHL) solution, it was incubated for 60 minutes at $37^{\circ} \mathrm{C}$. Post- incubation, the reaction was further stopped via the addition of 250 $\mu \mathrm{L}$ of $1 \mathrm{M}$ hydrochloric acid $(\mathrm{HCl})$. The mixture was then added with $1.5 \mathrm{~mL}$ ethyl acetate to extract the reaction's product, hippuric acid (HA). The mixture was then centrifuged at $3000 \mathrm{rpm}$ for 15 minutes. The supernatant of the mixture was then taken by one $\mathrm{mL}$, transferred to a five $\mathrm{mL}$ test tube, and allowed to evaporate in water bath at a temperature of $80^{\circ} \mathrm{C}$ until all solvents evaporated. Post-evaporation, the HA that remained in the test tube was then dissolved in $1 \mathrm{~mL}$ deionized water. One $\mathrm{mL}$ of the solution was put into the $1 \mathrm{~mL}$ cuvette before being measured using UV-VIS spectrophotometer at $228 \mathrm{~nm}$ wavelength using deionized water as the blank. The absorbance for all samples was measured in triplicates.

Since ASP gave the highest ACE inhibition activity at $100 \mathrm{mg} / \mathrm{mL}$, ASP was further tested at six different concentrations $(1,5,50,100,500$ and $1000 \mu \mathrm{g} / \mathrm{mL}$ ).

Fifty $\mathrm{uL}$ of samples and $50 \mu \mathrm{L}$ of ACE $(0.05 \mathrm{mU} / \mu \mathrm{L})$ were mixed and pre-incubated for 10 minutes at $37^{\circ} \mathrm{C}$. Then, HHL solution was added into the mixture before further incubation at $37^{\circ} \mathrm{C}$ for 60 minutes. The reaction was stopped by adding $250 \mu \mathrm{L}$ of $1 \mathrm{M}$ of $\mathrm{HCl}$. HA extraction was then proceeded by adding $1.5 \mathrm{~mL}$ of ethyl acetate into the reaction mixture. The mixture was then centrifuged at $3000 \mathrm{rpm}$ for 15 minutes before $1 \mathrm{~mL}$ of supernatant was transferred to a $5 \mathrm{~mL}$ test tube for ethyl acetate removal. The test tubes were placed in a water bath at a temperature of $80^{\circ} \mathrm{C}$ until all ethyl acetate was removed via evaporation. The remnants were then re-dissolved in $1 \mathrm{~mL}$ deionized water before UV-VIS measurement at $228 \mathrm{~nm}$. The absorbance for each sample was measured in triplicate with deionized water as blank.

Equation 2 was used to calculate the percentage of ACE inhibition activity (\%) for each extract concentration. From the inhibition percentage, the dose-response curve was plotted using Graph Pad PRISM (Version 8.0.2, USA), and the concentration that causes 50 $\%$ ACE inhibition $\left(\mathrm{IC}_{50}\right)$ for the extract was determined using this software.

The percentage of ACE inhibition (\%) was calculated with the following Equation 2;

ACE inhibition $(\%)=\frac{A 1-A 2}{A 1-A 3} \times 100$

Where:

A1 is the absorbance of the ACE solution without an inhibitor (Plant extract and fractions)

A2 is the absorbance of the tested sample of extract

A3 is the absorbance of the buffer solution (a buffer was added instead of the ACE solution, HHL and sample)

\section{Protein precipitation test with Bovine Serum Albumin (BSA)}

Since some phytochemicals in the plant extract can interact by forming cross-link with protein and cause precipitation, the plant extract may also precipitate the ACE, which is also a type of protein. In order to check whether the extract inhibited ACE via protein precipitation, this study tested the ACE inhibitory effect of ASP in the presence of a protein called bovine serum albumin (BSA). ${ }^{12,13}$ Specifically, the test using BSA was used to study the ability of ASP to precipitate BSA and how it affects ASP's ACE inhibitory activity.

BSA stock solution was prepared by dissolving $1 \mathrm{mg}$ of BSA in $1 \mathrm{~mL}$ of buffer. Then BSA was further diluted to five different concentrations of $25,50,125,200$, and $250 \mu \mathrm{g} / \mathrm{mL}$. Fifty $\mu \mathrm{L}$ of BSA, $50 \mu \mathrm{L}$ of ASP (at its $\mathrm{IC}_{50}$ concentration of $\left.41 \mu \mathrm{g} / \mathrm{ml}\right)$, and $50 \mu \mathrm{L}$ of ACE $(0.05 \mathrm{mU} / \mathrm{mL})$ were mixed and then incubated at $37^{\circ} \mathrm{C}$ for $10 \mathrm{mins}$. Incubation for $60 \mathrm{~min}$ proceeded after the addition of $150 \mu \mathrm{L}$ HHL solution. Then, the reaction 
was stopped by adding $300 \mu \mathrm{L}$ of $1 \mathrm{M} \mathrm{HCl}$, and then the reaction mixture was added with $1400 \mu \mathrm{L}$ ethyl acetate for HA extraction. The mixture was then centrifuged for 15 mins at $300 \mathrm{rpm}$. One $\mathrm{mL}$ supernatant was transferred to test a new test tube for ethyl acetate evaporation in a water bath with the temperature of $80^{\circ} \mathrm{C}$. Then, the extracted HA was re-dissolved in $1 \mathrm{~mL}$ deionized water for UV-VIS measurement at 228 $\mathrm{nm}$. Equation 2 was used to calculate the ACE inhibition activity in the presence of BSA. Then, the extract's ACE inhibition activity, with and without the presence of BSA was compared.

\section{Zinc chelation test}

Since some commercial ACE inhibitor drugs such as captopril cause ACE inhibition by interacting with the zinc at the active site of ACE, this study examined the ACE inhibition activity of ASP in the presence of zinc chloride. ${ }^{12,13}$ Fifty $\mu \mathrm{L}$ of $1.5 \mathrm{mM} \mathrm{ZnCl}_{2}$ was added to a tube containing $50 \mu \mathrm{L}$ of ASP $(41 \mu \mathrm{g} / \mathrm{mL})$ and $50 \mu \mathrm{L}$ of ACE enzyme $(0.05$ $\mathrm{mU} / \mu \mathrm{L}$ ) before incubation for 10 mins. The rest of the ACE inhibition assay was conducted, similar to the previously described method. ACE inhibition activities by ASP, with and without the presence of $\mathrm{Zn}^{2+}$ ions were calculated using equation 2 and then compared.

\section{Specificity of the enzyme inhibition by ASP}

The specificity of ACE inhibition by ASP was assessed by investigating its inhibition effect on other enzymes such as a-chymotrypsin and trypsin as described in previous studies with several modifications. ${ }^{12,13}$ a-Chymotrypsin stock enzyme was prepared by dissolving $2 \mathrm{mg}$ of a-chymotrypsin in $1 \mathrm{~mL}$ of $0.1 \mathrm{M}$ phosphate buffer $(\mathrm{pH} 8.0)$. The stock enzyme was then transferred for aliquot and stored at $-20^{\circ} \mathrm{C}$. The ASP stock solution was prepared by dissolving and diluting the sample in $100 \%$ dimethyl sulfoxide (DMSO) used for both $\alpha$-chymotrypsin and trypsin assay. Six $\mu$ Lof ASP at $41 \mu \mathrm{g} / \mathrm{mL}$ was added with $500 \mu \mathrm{L}$ of $20 \mu \mathrm{g} /$ $\mathrm{mL}$ of $\alpha$-chymotrypsin. After $5 \mathrm{~min}$ incubation, the mixture was then mixed with $1000 \mu \mathrm{L}$ of $2 \%$ casein and incubated further for $30 \mathrm{~min}$ at $37^{\circ} \mathrm{C}$. Post incubation, $2 \mathrm{~mL}$ of $10 \%$ trichloroacetate was added to stop the reaction and was allowed for 1 hour. The mixture was centrifuged at $5040 \mathrm{rpm}$ for 15 mins before the absorbance of the supernatant was measured at $280 \mathrm{~nm}$ using a microplate reader. Control consists of $6 \mu \mathrm{L}$ DMSO, enzyme, and also casein was tested along with sample solution. Absorbance measurements for all samples were repeated trice.

Trypsin stock enzyme was prepared by dissolving $1 \mathrm{mg}$ of the enzyme in $1 \mathrm{~mL}$ of $0.1 \mathrm{M}$ phosphate buffer ( $\mathrm{pH} 8.0$ ) before transferring it to each tube of $80 \mu \mathrm{L}$ for aliquot and then stored in $-20^{\circ} \mathrm{C}$ freezer. Six $\mu \mathrm{L}$ of the sample was mixed with $500 \mu \mathrm{L}$ of trypsin solution $(40 \mu \mathrm{g} / \mathrm{mL})$ and incubated for $5 \mathrm{~min}$ at $37^{\circ} \mathrm{C}$ in a laboratory oven. The mixture was then added with $1000 \mu \mathrm{L}$ of a-N-benzoyl-DL-arginine-P-nitroanilide $\mathrm{HCl}$ (BAPNA) solution and incubated for $20 \mathrm{~min}$ at $37^{\circ} \mathrm{C}$. BAPNA solution was prepared beforehand by dissolving $25 \mathrm{mg}$ of BAPNA in $0.5 \mathrm{~mL}$ DMSO and then diluted using $0.1 \mathrm{M}$ Tris- $\mathrm{HCl}$ buffer up to 50 $\mathrm{mL}$ (top up with buffer until $50 \mathrm{ml}$ ). In order to quench the reaction, 0.5 $\mathrm{mL}$ of $10 \%$ acetic acid was added, and the absorbance was measured at $410 \mathrm{~nm}$ via microplate reader. Assays were repeated for triplicate times.

Both $\alpha$-chymotrypsin and trypsin inhibition activity percentages (\%) were calculated using Equation 3 as shown below;

Enzyme inhibition $(\%)=\frac{C-S}{C} \times 100$

Where;

$\mathrm{C}$ is absorbance for the control, which consists of $6 \mu \mathrm{L}$ DMSO, enzyme, and substrate

$\mathrm{S}$ is absorbance for a sample of extract (ASP).

\section{Statistical analysis}

One-way ANOVA analysis, followed by post-hoc Tukey's multiple comparison test was conducted using $\mathrm{GraphPad}^{\circledR} \mathrm{PRISM}$ software (Version 8.0.2, USA) to compare ACE inhibition activity for the four types of crude extracts and standard drug. The same analysis was performed in comparing the inhibition activities of ASP towards ACE, trypsin, and chymotrypsin. A dose-response curve for ASP was constructed using non-linear sigmoid regression curve using the same software to obtain the $\mathrm{IC}_{50}$ value for ASP's ACE inhibition activity. Unpaired t-test was conducted to analyse the difference between ACE inhibition activity by ASP with and without the presence of BSA or $\mathrm{Zn}^{2+}$ ions. The value of $\mathrm{P}$ less than 0.05 was considered significant.

\section{RESULTS}

\section{Yield of extraction}

In total, $3.26 \mathrm{~kg}$ of dried $S$. polyanthum leaves were extracted in this study. From $3.26 \mathrm{~kg}$ of dried S. polyanthum leaves, the yield of ASP was $97.7 \mathrm{~g}(2.99 \%)$ (Table 1). Meanwhile, only $250 \mathrm{~g}$ was used for sequential extraction in yielding MSP, EASP, and HSP, as recorded in Table 1 . The yield of MSP extraction for this study was the highest, as much as 6.76 $\%$, followed by ASP, EASP, and HSP with percentage yields of $2.99 \%$, $0.68 \%$, and $0.28 \%$, respectively.

\section{ACE inhibition activity of S. Polyanthum extracts}

Among all samples, ASP exhibited the highest ACE inhibitory activity with $69.43 \%$, while others have also shown ACE inhibitory activity at lower percentages (Figure 1). The second-highest ACE inhibition activity was shown by HSP with $45.40 \%$, followed by MSP with 41.63 $\%$, and the lowest inhibition was by EASP with only $9.62 \%$ activity. The standard drug captopril at $2.06 \mathrm{ng} / \mathrm{mL}$ showed ACE inhibition of 74.95 $\%$. ASP's ACE inhibitory activity was significantly higher compared to the other three extracts $(\mathrm{P}<0.001)$.

ACE inhibition activity of the most active extract, ASP was further tested at varying concentrations ranging between $1,5,50,100,500$, and $1000 \mu \mathrm{g} / \mathrm{mL}$. Table 2 illustrates the ACE inhibition activity percentages of ASP at each concentration. A dose-response curve for ASP's ACE inhibitory activity was shown in Figure 2 . From this dose-response curve, the calculated $\mathrm{IC}_{50}$ value for ASP's ACE inhibitory activity was $41 \mu \mathrm{g} / \mathrm{mL}$.

\section{Protein precipitation test with Bovine Serum Albumin (BSA)}

The ACE inhibitory activity of ASP $(41 \mu \mathrm{g} / \mathrm{mL})$ was significantly reduced by $71.75 \%$ with the presence of BSA $(\mathrm{P}<0.0001$, Table 3$)$.

\section{Effect of Zinc Chloride $\left(\mathrm{ZnCl}_{2}\right)$ on the inhibitory activity of ACE}

The presence of $\mathrm{Zn}^{2+}$ reduced the ASP's ACE inhibitory activity, however, the reduction was not significantly different (Table 4).

\section{Assessment of specificity of enzyme inhibition by ASP against chymotrypsin and trypsin}

When ASP at $41 \mu \mathrm{g} / \mathrm{mL}$ was further tested on different enzymes like chymotrypsin and trypsin, ASP did not show any significant inhibition activity towards chymotrypsin or trypsin with the inhibition activity values of $0.91 \pm 0.16 \%$ and $3.23 \pm 0.54 \%$, respectively (Table 5). The ASP's inhibition activity on ACE was significantly different than the inhibition activity of chymotrypsin and trypsin $(\mathrm{P}<0.01)$.

\section{DISCUSSION}

This study explores the ACE inhibition activity by $S$. polyanthum leaves extract, its mechanism and specificity. Initially, there were four 
Table 1: Extraction yield results for ASP, HSP, EASP and MSP.

\begin{tabular}{|c|c|c|c|c|c|c|c|}
\hline \multicolumn{8}{|c|}{ Final Yields } \\
\hline \multicolumn{2}{|c|}{ Aquoues (ASP) } & \multicolumn{2}{|c|}{ n-Hexane (HSP) } & \multicolumn{2}{|c|}{ Ethyl Acetate (EASP) } & \multicolumn{2}{|c|}{ Methanol (MSP) } \\
\hline $\begin{array}{l}\text { Weight } \\
\text { (g) }\end{array}$ & $\begin{array}{c}\text { Percent } \\
\text { Weight } \\
(\%)\end{array}$ & $\begin{array}{l}\text { Weight } \\
\text { (g) }\end{array}$ & $\begin{array}{c}\text { Percent } \\
\text { Weight } \\
(\%)\end{array}$ & $\begin{array}{c}\text { Weight } \\
\text { (g) }\end{array}$ & $\begin{array}{c}\text { Percent } \\
\text { Weight } \\
(\%)\end{array}$ & $\begin{array}{c}\text { Weight } \\
\text { (g) }\end{array}$ & $\begin{array}{c}\text { Percent } \\
\text { Weight } \\
(\%)\end{array}$ \\
\hline 97.7 & 2.99 & 0.70 & 0.28 & 1.70 & 0.68 & 16.90 & 6.76 \\
\hline
\end{tabular}

Table 2: ACE inhibition activity of ASP (1-1000 $\mu \mathrm{g} / \mathrm{mL})$.

\begin{tabular}{|c|c|c|c|c|}
\hline & $\begin{array}{c}\text { Concentration } \\
(\mu \mathrm{g} / \mathrm{mL})\end{array}$ & $\begin{array}{c}\log \\
{[\text { ASP }(\mu \mathrm{g} / \mathrm{mL})]}\end{array}$ & $\begin{array}{l}\text { Average } \\
(n=3)\end{array}$ & SD \\
\hline \multirow{6}{*}{ ASP } & 1000 & 3.00 & 63.01 & 0.519 \\
\hline & 500 & 2.70 & 69.85 & 1.194 \\
\hline & 100 & 2.00 & 58.48 & 0.119 \\
\hline & 50 & 1.70 & 47.85 & 0.156 \\
\hline & 5 & 0.70 & 45.02 & 0.325 \\
\hline & 1 & 0 & 33.51 & 0.992 \\
\hline $\begin{array}{l}\text { Positive control } \\
\text { (Captopril, in ng/mL) }\end{array}$ & 2.06 & - & 75.71 & 0.450 \\
\hline
\end{tabular}

*triplicate readings. SD: Standard Deviation.

Table 3: BSA protein precipitation.

\begin{tabular}{|c|c|c|c|}
\hline \multicolumn{3}{|c|}{ ACE Inhibition of Activity of ASP $(41 \mu \mathrm{g} / \mathrm{mL})$} & \multirow[b]{2}{*}{ P-Value } \\
\hline $\begin{array}{c}\text { Absence of BSA } \\
(\% \pm S D)\end{array}$ & $\begin{array}{c}\text { Presence of BSA } \\
(\% \pm \mathrm{SD})\end{array}$ & $\%$ Decrease in activity & \\
\hline $87.70 \pm 2.20$ & $24.77 \pm 4.57$ & 71.75 & $<0.0001$ \\
\hline
\end{tabular}

${ }^{*} \mathrm{n}=3$ replicates. SD: Standard Deviation.

Table 4: Effect of zinc chloride on ASP's ACE inhibitory activity.

\begin{tabular}{|c|c|c|c|}
\hline \multicolumn{3}{|c|}{ ACE Inhibition of activity of ASP $(41 \mu \mathrm{g} / \mathrm{mL})$} & \multirow[b]{2}{*}{ P-Value } \\
\hline $\begin{array}{l}\text { Absence of } \mathrm{ZnCl}_{2} \\
(\% \pm \mathrm{SD})\end{array}$ & $\begin{array}{l}\text { Presence of } \mathrm{ZnCl}_{2} \\
(\% \pm \mathrm{SD})\end{array}$ & $\%$ Decrease in activity & \\
\hline $47.05 \pm 3.78$ & $39.99 \pm 6.03$ & 15 & 0.5647 \\
\hline
\end{tabular}

${ }^{*} \mathrm{n}=3$ replicates. SD: Standard Deviation.

Table 5: Specificity of ASP enzyme inhibition.

\begin{tabular}{ccccc}
\hline \multirow{2}{*}{ Enzymes } & $\begin{array}{c}\text { Concentration tested } \\
(\mu \mathrm{g} / \mathrm{mL})\end{array}$ & \multicolumn{2}{c}{ Inhibition Activity (\%) } & P value \\
\cline { 3 - 4 } Chymotrypsin & 41 & 0.91 & SD & 0.16 \\
Trypsin & 41 & 3.23 & 0.54 & 0.002 \\
ACE & 41 & 62.73 & 5.18 & \\
\end{tabular}

${ }^{*} \mathrm{P}<0.01, \mathrm{ASP}$ 's ACE inhibition activity vs. ASP's trypsin and chymotrypsin inhibition activity. SD: Standard Deviation.

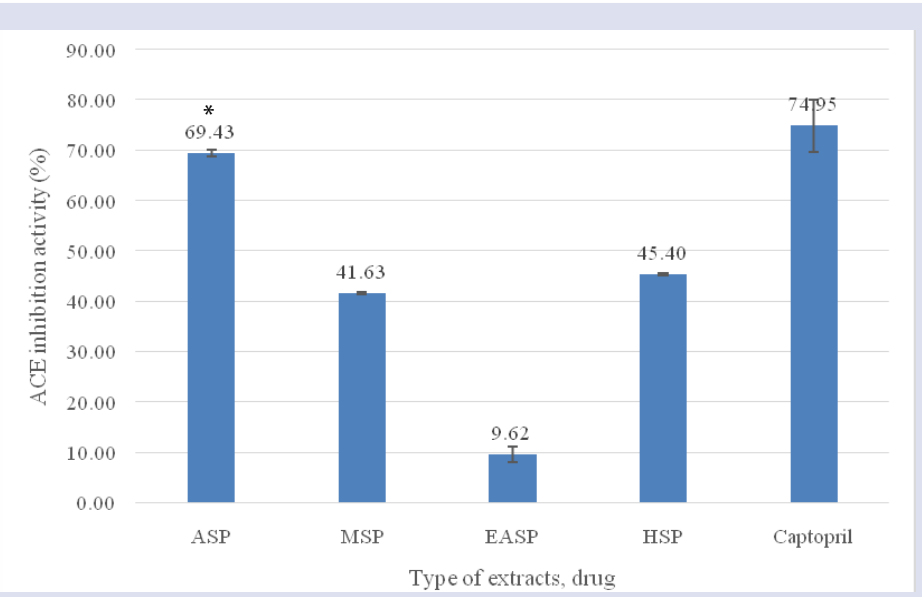

Figure 1: Angiotensin-Converting Enzyme inhibition activity screening of all samples at $100(\mu \mathrm{g} / \mathrm{mL})$ and captopril $(2.06 \mathrm{ng} / \mathrm{mL})$. ${ }^{*} \mathrm{P}<0.001$ for ASP vs. other types of extracts (MSP, HSP, EASP). 


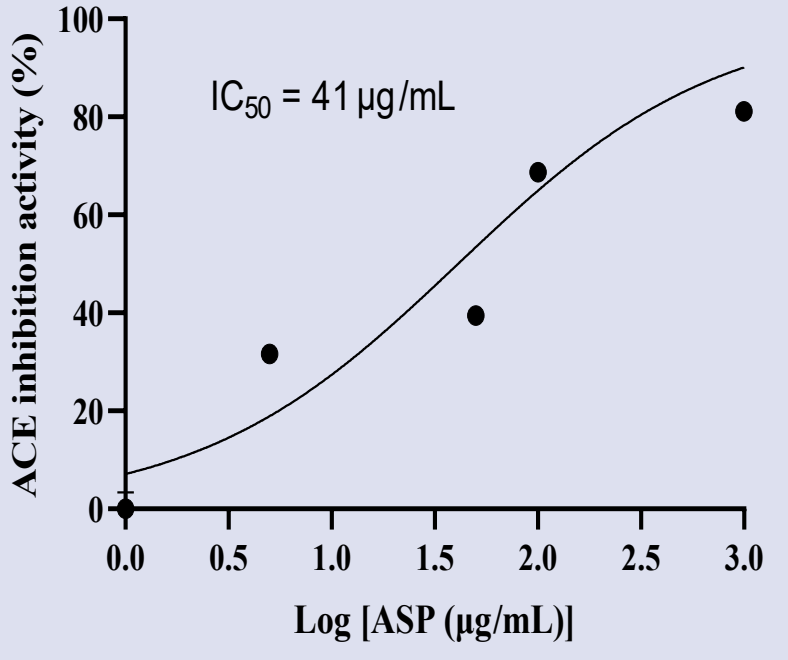

Figure 2: Dose-response curve for ACE inhibition activity by ASP and its IC ${ }_{50}$

different types of extracts used in this study which include the aqueous (ASP), hexane (HSP), ethyl acetate (EASP) and methanolic (MSP) extracts of $S$. polyanthum leaves. These were extracted using four different solvents having different polarity index such as water (10.2), methanol (5.1), ethyl acetate (4.4), and n-hexane (0.1). Water was used to extract compounds such as gallotannins, phenolic acids, glucosides, flavonoids, and simple phenols. ${ }^{14}$ More importantly, the use of water as a solvent was actually to mimic the traditional process of preparing the sample. ${ }^{15}$ However, not all compounds can be extracted through aqueous extraction, thus sequential solvent extraction is also utilized to extract other compounds such as aldehydes, terpenes, fatty acids, esters as well as phenolics that could not be extracted through aqueous extraction. ${ }^{4,15}$

Among the four types of extracts, the highest extraction yield was for MSP followed by ASP, EASP and HSP. The order of the yield in this study actually conforms with previous study on S. polyanthum that utilized the same extraction method. ${ }^{14}$ Solvents with different polarities have their specific functions in extracting compounds. The non-polar n-hexane was usually utilized to breakdown the coated phospholipid cell wall, meanwhile the ethyl acetate was utilized to extract hydrophilic and lipophilic compounds present in the sample. Further step of sequential extraction with polar solvent such as ethanol was used to extract the remaining compounds such as polyphenols. ${ }^{16}$

EASP and HSP were the two extracts with the lowest yields of $0.68 \%$ and $0.28 \%$, respectively. This is most likely because of the low composition of the non-polar to semi-polar compounds in S. polyanthum leaves. Previous GC-MS analysis study on the n-hexane extract of $S$. polyanthum leaves showed the presence of some non-polar terpenes and several phenols with long aliphatic chain, while the ethyl acetate extract consisted of some non-polar terpenes with several semi-polar compounds. ${ }^{17}$ As for MSP, extraction with methanol gave higher yield than water. This is aligned with the previous studies on S. polyanthum ${ }^{14}$, Limnophila armatica ${ }^{18}$ and Datura metel. ${ }^{19}$ Extraction with methanol gave higher yield than the water possibly because of the inactivity of polyphenol oxidase in the methanol solvent, thus leading to higher yield of polyphenols in the methanol extract. ${ }^{15}$ In contrast, polyphenol oxidase enzyme is active in the aqueous extract, causing polyphenols present in the aqueous extract to be degraded, thus lowering the number of polyphenols being extracted. Another plausible explanation is most likely because water solvent is less efficient in degrading the cell wall as compared to methanol, this leads to the reduced number of polyphenols released from the cell. The third factor most probably due to the high temperature used during water extraction, which has caused some compounds to be degraded. ${ }^{20}$

ACE inhibition assay is one of the common in vitro assays that shows the antihypertensive potential of any drugs or plants extracts. During initial screening for ACE inhibition activity, all four types of $S$. polyanthum leaves extracts showed significant ACE inhibition activity with the highest activity was shown by ASP (69.43\%). This finding was in agreement with a previous in vivo study which demonstrated that ASP has the highest efficacy in reducing the blood pressure of Spontaneously Hypertensive Rats, in comparison to the other types of extracts. ${ }^{14}$ In corroboration with our finding, the water extract of Chassalia curviflora leaves and flowers have also shown a high ACE inhibition activity. ${ }^{21}$

Besides ASP, the other three extracts (MSP, EASP and HSP) also showed significant ACE inhibition activity in a decreasing order of HSP $>$ MSP $>$ EASP. This conforms with previous study on Gnetum gnemon seeds, in which this study showed that the ACE inhibition of the non-polar extract was as high as its semi-polar and polar extracts. ${ }^{22}$ Thus, apart from the usage of polar solvents, non-polar solvents might as well be useful in extracting some compounds with ACE inhibiting activities.

As for MSP, this study found that MSP have a moderate ACE inhibition activity ( $41.63 \%)$. In comparison to the previous study by Muthia et al ${ }^{8}$ on $S$. polyanthum leaves, they found that the ethanol extract of this plant showed significant ACE inhibition activity with the percentage of $53.37 \%$. Similarly, there were several studies on other plants such as Apium graviolens ${ }^{23}$ and Chassalia curviflora ${ }^{21}$ that showed significant ACE inhibition activity by the methanol extract.

EASP in this study has the lowest ACE inhibition activity. This is aligned with a previous study done by Rinayanti et $a^{24}$ on Hibiscus rosasinensis, in which its ethyl acetate extract was less potent as compared to its methanol extract. However, there were some other studies showing that ethyl acetate extract possessed a high ACE inhibition activity. For example, ethyl acetate extract from G. gnemon shows the highest ACE inhibition activity than the polar solvent. ${ }^{22}$ Another study was done specifically on ethyl acetate extract of Anacardium occidentale from Thailand also showed a good ACE inhibition activity with percentage of $64.20 \%$ at $5 \mathrm{mg} / \mathrm{mL}$. In other words, the ACE inhibition activity is dependent upon the presence of the specific bioactive phytochemical constituents in each plant, and thus, these vary greatly from plant to plant.

Through this study, ASP was shown as having the highest ACE inhibition activity among the samples, followed by hexane, methanol, and ethyl acetate. This inhibition result is quite similar to in vivo study of the same plant done by Ismail $e t a^{14}$ with ASP was shown to give the highest antihypertensive effects by reducing the blood pressure of spontaneously hypertensive rats as compared with the other types of solvent-based extracts. Based on this result, ASP was then further studied on its potency, mechanism of ACE inhibition, inhibition specificity, as well as its phytochemical constituents.

Since ASP exhibited the highest ACE inhibition activity in comparison to the other types of extracts, the potency of ASP in inhibiting the ACE was further studied by searching for its concentration that causes 50 $\%$ of ACE inhibition $\left(\mathrm{IC}_{50}\right) . \mathrm{IC}_{50}$ is a usual indicator of potency and is used when the inhibitor is a competitor of a ligand binding to a receptor. ${ }^{25}$ The $\mathrm{IC}_{50}$ value of ASP in this study was found to be at 41 $\mu \mathrm{g} / \mathrm{mL}$. In comparison with other plant extracts, the aqueous extract of C. curviflora flower and leaves showed the highest $\mathrm{IC}_{50}$ among plants prepared through aqueous solvent with the $\mathrm{IC}_{50}$ value of 3.39 and 4.96 
$\mu \mathrm{g} / \mathrm{mL}$, respectively. ${ }^{21}$ Several mushroom species such as Ganoderma lucidum and Pluerotus florida meanwhile showed a higher $\mathrm{IC}_{50}$ value of $50 \mu \mathrm{g} / \mathrm{mL} .{ }^{26}$ This indicates that ASP has the potential of ACE inhibiting properties which seems to be at par with few other aqueous plant extracts. Nevertheless, the comparison was not explicit as each of the previous studies on other plants have used different ACE inhibition assay methods.

Phytochemical compounds such as tannins have the ability to conjugate with protein, and thus has the ability to non-specifically inhibit the enzyme action. ${ }^{13}$ In order to determine if the plant extract inhibits ACE via protein precipitation, this study utilized bovine serum albumin which is chemically similar to the human serum albumin. ${ }^{27}$ In fact, the ACE inhibitor drug, captopril did bind strongly to the albumin as shown via in vivo and in silico study. ${ }^{28}$ In this study, the ACE inhibition activity by ASP in the presence of BSA was found to be significantly reduced as much as $71.75 \%$.This showed that ASP could bind with the protein (albumin), causing protein precipitation, leading to its ACE inhibition activity. The ability to cause protein precipitation perhaps due to the crosslink that occurs between the phenolics in ASP with the protein. ${ }^{29}$ Similar finding was actually observed with few other plants, for instance, the ACE inhibiting activity of Crataegus oxyacantha extract was shown to be reduced up to $61.66 \%$ in the presence of BSA. Similarly, Coscinium fenestratum extract had also shown a significant reduction in ACE inhibition activity with the value of reduction as high as $86.49 \%$ in the presence of BSA. ${ }^{12}$

In contrast, there were also other plant extracts or fractions that have ACE inhibition properties but have shown lower BSA precipitation. Cynara scolymus ethyl acetate fraction for example, only have a slight reduction in its activity as low as $1.73 \%$, as well as Stevia rebaudiana aqueous fraction with the reduction in activity by only $5.09 \%$. Both plants were concluded to have an insignificant interaction with BSA. ${ }^{12}$ It was postulated that such inhibition may not be coming from the binding interaction within the active site, instead of that, the binding might occur on the outside of the ACE molecule. ${ }^{30}$

ACE is a zinc metallo protease with zinc ion are found within the catalytic active site, which is significant for enzyme activity. In view of this matter, non-specific metal chelators may possibly behave as ACE inhibitors. ACE active site consists of three parts: a carboxylate binding functionality, a hydrophobic side chain pocket, and a zinc ion. Supplementation of $\mathrm{ZnCl}_{2}$ in the ACE activity test system is to determine whether there is reduction of ASP's ACE inhibition activity that are caused by $\mathrm{Zn}^{2+}$ ion chelation. A previous study has shown that some plants showed a notable reduction in the ACE inhibition activity when introduced with $\mathrm{Zn}^{2+}$ ions. For example, the ACE inhibition activity of Embeliaribes was significantly reduced by $58.39 \%$ with the presence of $\mathrm{ZnCl}_{2}{ }^{12}$ The ACE inhibition activity by tannins, specifically caffeoylquinates were also shown to be significantly affected in the presence of $\mathrm{ZnCl}_{2}$ with reduction percentage of 24.96 to $26.58 \%{ }^{13}$

In contrast to that, our current study has shown that for ASP, the presence of $\mathrm{Zn}^{2+}$ only slightly reduced the ASP's ACE inhibitory activity with $15 \%$ decrease in activity. The reduction was not significantly different with a p-value of 0.5647 . Therefore, the finding suggested that ASP did not significantly inhibit the ACE via chelation with $\mathrm{Zn}$ metal in the active site of ACE enzyme. With reference to the previous study by Khan \& Kumar, ${ }^{12}$ there were also several plants that showed similar findings with our study. For example, Mucuna pruriens showed insignificant changes on the ACE inhibition activity with only $2.86 \%$ decrease in activity in the presence of $\mathrm{ZnCl}_{2}$. Meanwhile C. scolymus extract had shown slight reduction in ACE inhibition by only $1.91 \%$ when it was introduced to $\mathrm{Zn}^{2+}$ ions. Similarly, enalaprilat, an active metabolite from enalapril have a weak interaction with zinc ion. Despite so, other binding interactions occur between enaprilat and other ACE residues which still causes the ACE inhibition. ${ }^{31}$
In order to test whether ASP is a specific or non-specific inhibitor towards ACE, other enzymes are utilized to test the inhibition ability of ASP. Among the available enzymes, trypsin and chymotrypsin are chosen as both enzymes are particularly involved with protein digestion. Inhibition of these two enzymes usually will lead to the reduction in the dietary protein digestion and absorption in the duodenum of the digestive system. ${ }^{32}$ It was shown in this study that ASP specifically inhibits ACE enzyme only, and has no significant inhibition towards trypsin and chymotrypsin enzymes. This illustrates that ASP is not only being a specific ACE inhibitor, but it also has the advantage of not interfering with the digestive system. This finding was actually similar to a previous study by Khan \& Kumar ${ }^{12}$ on Coscinium fenestratum fraction. They reported that $C$. fenestratum fraction has specific enzyme inhibition of only towards ACE at $51.30 \%$ inhibition activity, with only $7.23 \%$ and $4.19 \%$ towards trypsin and chymotrypsin, respectively. ${ }^{12}$

De Freitas $^{33}$ in his study showed different results with their plant peptides, showing inhibition towards all the tested enzymes which include ACE, trypsin as well as chymotrypsin. This illustrates that their samples are non-specific inhibitors of ACE. In another study, Cassia occidentallis fraction, C. scolymus fraction, and E.ribes fraction were concluded as non-specific inhibitors of ACE by showing a significant inhibition towards chymotrypsin and trypsin enzymes. ${ }^{12}$

\section{CONCLUSION}

This study found that the aqueous extract of Syzygium polyanthum leaves (ASP) have a dose-dependent ACE inhibition activity that acts partly via protein precipitation, but the inhibition was not-dependent to the interaction with zinc metal ion at the ACE active site. ASP did not inhibit trypsin and chymotrypsin.

\section{ACKNOWLEDGEMENT}

This project is mainly funded by the Ministry of Higher Education, Malaysia [Grant number: FRGS/1/2018/SKK10/UIAM/02/1] and Bayamedic Services [Grant number: SPP21-045-0045] for publication. The authors would like to acknowledge the staff at Natural Product Laboratory and Centre Research Animal Facility (CREAM), Kulliyyah of Science, International Islamic University Malaysia (IIUM) for providing technical support in carrying out this experiment.

\section{CONFLICTS OF INTEREST}

The authors declare that there is no conflicts of interest.

\section{REFERENCES}

1. Mills KT, Stefanescu A, He J. The global epidemiology of hypertension. Nat Rev Nephrol. 2020;16:223-237.

2. Lee JY, Han SH. Blood pressure control in patients with chronic kidney disease. The Korean J Intern Med. 2021;36:780.

3. Hanafi MA, Hashim SN, Chay SY. High angiotensin-I converting enzyme (ACE) inhibitory activity of Alcalase-digested green soybean (Glycine max) hydrolysates. Food Res Intern. 2018;106:589-597.

4. Ismail A, Ahmad WANW. Syzygium polyanthum (Wight) Walp: A potential phytomedicine. Pharmacognosy Journal. 2019;11.

5. Ismail A, Mohamed M, Sulaiman SA, Wan Ahmad WAN. Autonomic nervous system mediates the hypotensive effects of aqueous and residual methanolic extracts of Syzygium polyanthum (Wight) Walp. var. polyanthum leaves in anaesthetized rats. Evid-based Complement Altern Med. 2013.

6. Ismail A, Ahmad WANW. Autonomic receptors and nitric-oxide involvements in mediating vasorelaxation effect induced by Syzygium polyanthum leaves extract. Pharmacogn Res. 2017;9. 
7. Ramli NS, Muhammad NA, Safuan S, Noordin L. Preliminary evaluation on the effect of methanolic extract from Syzygium polyanthum on improvement of hypertensive-renal damage among spontaneous hypertensive rat models. Ann Microsc. 162017:15-22.

8. Muthia R, Suganda AG, Sukandar EY. Angiotensin-I Converting Enzyme (ACE) inhibitory activity of several Indonesian medicinal plants. Res J Pharm, Biol Chem Sci. 2017;8:192-199.

9. Tutor JT, Chichioco-Hernandez CL. Angiotensin-converting enzyme inhibition of fractions from Eleusine indica leaf extracts. Pharmacogn J. 2018;10:25-28.

10. Cushman D, Cheung H. Spectrophotometric assay and properties of the angiotensin-converting enzyme of rabbit lung. Biochem Pharmacol. 1971;20:1637-1648.

11. Chen J, Wang $Y, Y e R, W u Y, X i a$ W. Comparison of analytical methods to assay inhibitors of angiotensin I-converting enzyme. Food Chem. 2013;141:3329-3334.

12. Khan MY, Kumar V. Mechanism \& inhibition kinetics of bioassayguided fractions of Indian medicinal plants and foods as ACE inhibitors. JTrad Complement Med. 92019:73-84.

13. Liu J-C, Hsu F-L, Tsai J-C. Antihypertensive effects of tannins isolated from traditional Chinese herbs as non-specific inhibitors of angiontensin converting enzyme. Life Sci. 2003;73:1543-1555.

14. Ismail A, Rahim ENAA, Omar MN, Ahmad WANW. Antihypertensive assay-guided fractionation of Syzygium polyanthum leaves and phenolics profile analysis using LCOTOF/MS. Pharmacogn J. 2020;12:1670-1692.

15. Tiwari P, Kumar B, Kaur M, Kaur G, Kaur H. Phytochemical screening and extraction: a review. Int Pharm Sci. 2011;1:98-106.

16. Sulmartiwi L, Pujiastuti DY, Tjahjaningsih W, Jariyah. Potential of mangrove Avicennia rumphiana extract as an antioxidant agent using multilevel extraction. IOP Conf Ser: Earth Environ Sci. 2018;137.

17. Abd Rahim ENA, Ismail A, Omar MN, Rahmat UN, Nizam Wan Ahmad WA. GC-MS analysis of phytochemical compounds in Syzygium polyanthum leaves extracted using ultrasound-assisted method. Pharmacogn J. 102018:110-119.

18. Do QD, Angkawijaya AE, Tran-Nguyen PL. Effect of extraction solvent on total phenol content, total flavonoid content, and antioxidant activity of Limnophila aromatica. J Food Drug Anal. 2014;22:296-302.

19. Dhawan D, Gupta J. Comparison of different solvents for phytochemical extraction potential from Datura metel plant leaves. Int J Biol Chem. 2016;11:17-22.
20. Lapornik B, Prošek M, Wondra AG. Comparison of extracts prepared from plant by-products using different solvents and extraction time. J Food Eng. 2005;71:214-222.

21. Kadir WNHW, Omar NAM. Antihypertensive activity and phytochemicals analysis of Chassalia curviflora extracts. 2014.

22. Mun'im A, Munadhil MA, Puspitasari N, Yanuar A. Angiotensin converting enzyme inhibitory activity of Melinjo (Gnetum gnemon L.) seed extracts and molecular docking of its stilbene constituents. Asian J Pharm Clin Res. 2017;10:243-248.

23. Simaratanamongkol A, Umehara K, Noguchi H, Panichayupakaranant $P$. Identification of a new angiotensin-converting enzyme (ACE) inhibitor from Thai edible plants. Food Chem. 2014;165:92-97.

24. Rinayanti A, Radji M, Mun'im A, Suyatna F. Screening angiotensin converting enzyme (ACE) inhibitor activity of antihypertensive medicinal plants from Indonesia. Int J Pharm Teach Pract. 2013;4:527-532.

25. MarÉchal E. Measuring bioactivity: $\mathrm{KI}_{1} \mathrm{IC}_{50}$ and $\mathrm{EC}_{50}$. Chemogenomics and Chemical Genetics: Springer; 2011;55-65.

26. Abdullah N, Ismail SM, Aminudin N, Shuib AS, Lau BF. Evaluation of selected culinary-medicinal mushrooms for antioxidant and ACE inhibitory activities. EvidBased Complement Altern Med. 2012.

27. Sulkowska A. Interaction of drugs with bovine and human serum albumin. J Molecular Struct. 2002;614:227-232.

28. Khatun S. Probing of the binding profile of anti-hypertensive drug captopril with bovine serum albumin: a detailed calorimetric, spectroscopic and molecular docking studies. J Chem Thermodyn. 2018;126:43-53.

29. Baxter NJ, Lilley TH, Haslam E, Williamson MP. Multiple interactions between polyphenols and a salivary proline-rich protein repeat result in complexation and precipitation. Biochem. 1997;36:5566-5577.

30. Al Shukor N, Van Camp J, Gonzales GB. Angiotensin-converting enzyme inhibitory effects by plant phenolic compounds: A study of structure activity relationships. JAgric Food Chem. 2013;61:1183211839.

31. Raia Jr JJ, Barone JA, Byerly WG, Lacy CR. Angiotensin-converting enzyme inhibitors: a comparative review. DICP. 1990;24:506-525.

32. Avilés-Gaxiola S, Chuck-Hernández C, Serna Saldivar SO. Inactivation methods of trypsin inhibitor in legumes: a review. J Food Sci. 2018;83:17-29.

33. De Freitas MAG, Amaral NO, Álvares AdCM. Blood pressurelowering effects of a Bowman-Birk inhibitor and its derived peptides in normotensive and hypertensive rats. Sci Rep. 2020;10:1-15. 


\section{GRAPHICAL ABSTRACT}

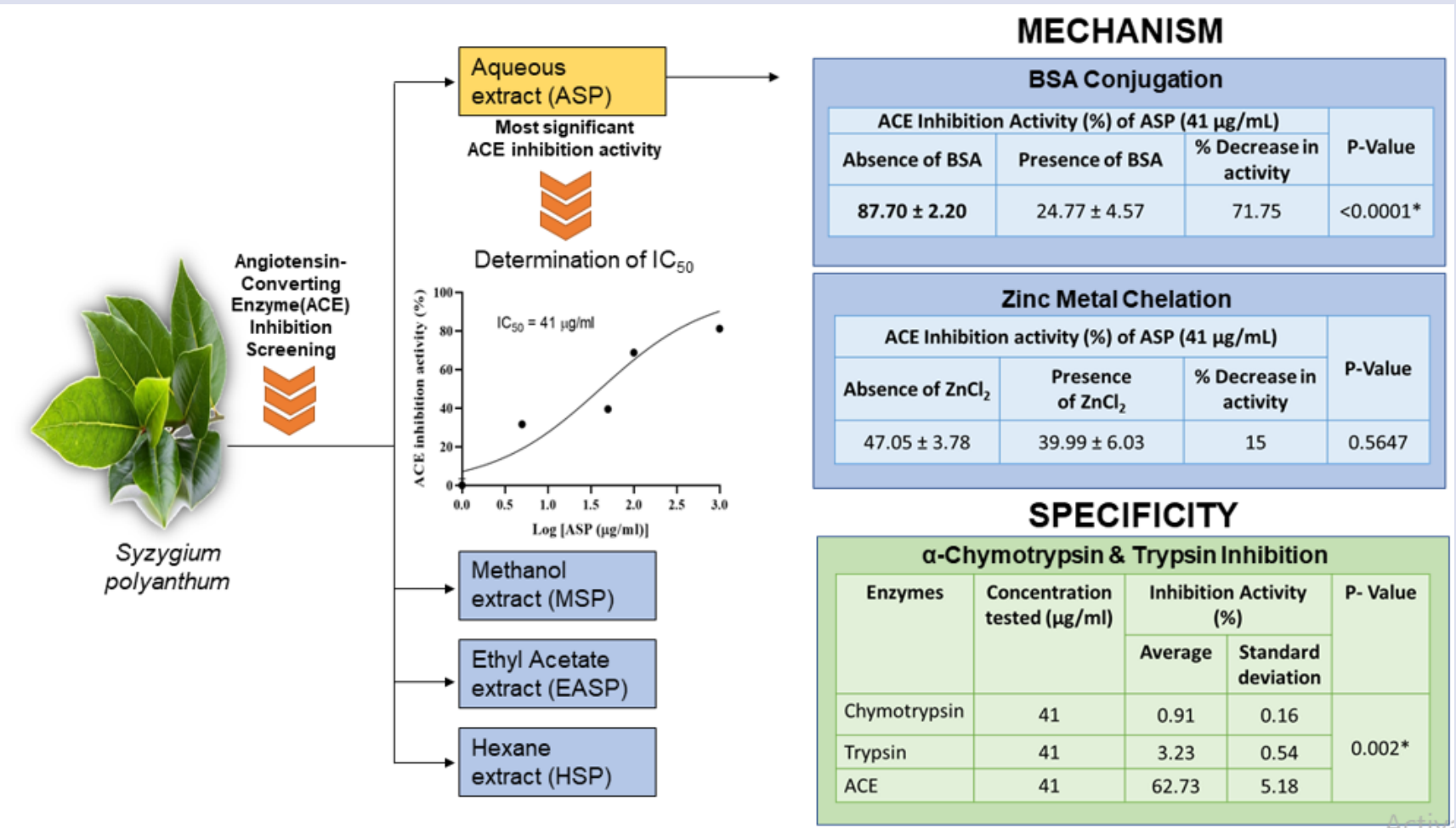

\section{ABOUT AUTHORS}
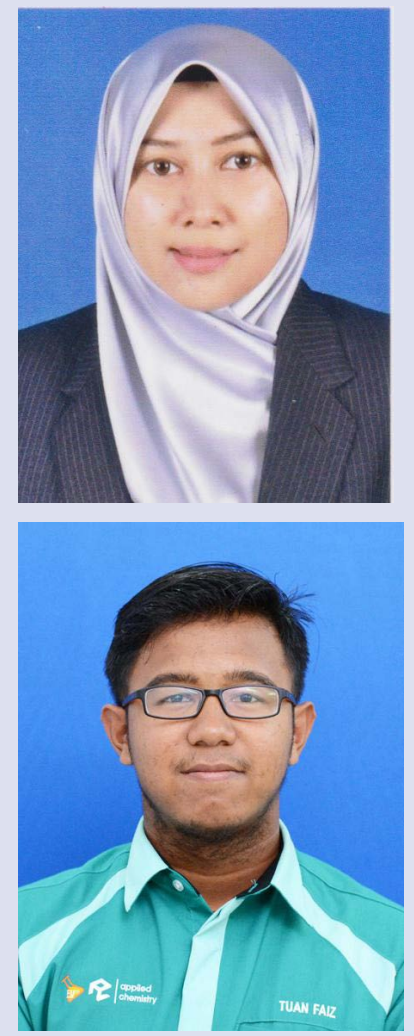

Azlini Ismail is an Assistant Professor (senior lecturer) at the Department of Fundamental Dental and Medical Sciences, Kulliyyah of Dentistry (KOD), International Islamic University Malaysia (IIUM). She is currently the Head of Research \& Responsible Innovation of KOD, IIUM. Her research interests include cardiovascular pharmacology, pharmacognosy, natural product, and traditional medicine.

Tuan Ashraf Faiz already completed his Master of Science's degree in Chemistry under the Department of Chemistry, Kulliyyah of Science, International Islamic University Malaysia (IIUM). Currently pursuing his PhD in Systems Biology under the Institute of System Biology, Universiti Kebangsaan Malaysia. 

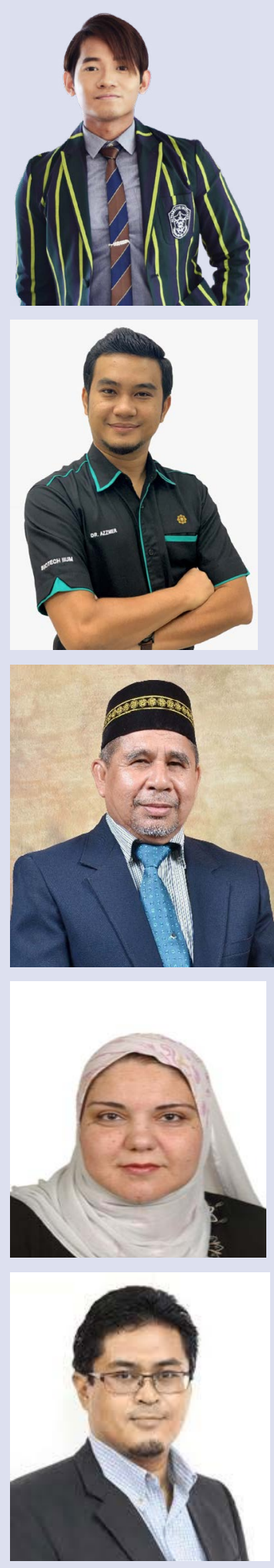

Izzat Fahimuddin Mohamed Suffian is currently an Assistant Professor at the Department of Pharmaceutical Technology, Kulliyyah of Pharmacy, International Islamic University Malaysia. Izzat is currently leading his own research group, Izzat Nanomedicine Research Group (INAREG), mainly to develop novel nanostructured materials and formulations to carry diagnostic and therapeutic compounds across biological barriers to be delivered to the target tissues and organs.

Azzmer Azzar Abdul Hamid is an Associate Professor from the Department of Biotechnology, Kulliyyah (Faculty) of Science, International Islamic University Malaysia (IIUM). He is currently exco for Malaysian Society of Bioinformatics \& Computational Biology (MasBIC). His research interest is on Molecular Modeling and Rational Design of Environmental and Disease proteins.

Muhammad Nor Omar is a retired professor from the Department of Biotechnology, Kulliyyah (Faculty) of Science, International Islamic University Malaysia (IIUM). He was active in natural products research besides developing products from palm oil oleochemicals.

Basma Ezzat Mustafa is an Associate Professor at the Department of Fundamental Dental and Medical Sciences, Kulliyyah of Dentistry (KOD), International Islamic University Malaysia (IIUM). She is currently the Head of the Basic Medical Science Unit in the faculty. Her research interests include pharmacology, microbiology, immunology, and natural products.

Wan Amir Nizam Wan Ahmad is currently a Senior Lecturer at the School of Health Sciences, Universiti Sains Malaysia. His research interest includes natural product pharmacology, cardiovascular disease, and animal model of disease.

Cite this article: Ismail A, AnuarTAFT, Suffian IFM, Abdul Hamid AA, Omar MN, Mustafa BE, et al. Angiotensin Converting Enzyme (ACE) Inhibition Activity by Syzygium polyanthum Wight (Walp.) Leaves: Mechanism and Specificity. Pharmacogn J. 2022;14(1): 76-84. 